\title{
LEADERSHIP TRAINING FOR ALL: PROVIDING OPPORTUNITIES FOR DEGREED AND NON-DEGREED LIBRARIANS IN A REGIONAL INSTITUTE
}

\author{
Janelle M. Zauha \\ Montana State University Libraries, \\ PO Box 173320 \\ Bozeman, MT 59717-3320, USA \\ jzauha@montana.edu
}

\begin{abstract}
Developing library leaders for the future is an issue of global concern. Faced with rapidly changing roles, escalating ethical and political challenges, and varied precareer educational opportunities, our profession is looking for the best ways to identify and nurture new leaders from all levels of its ranks. This paper focuses on one region's efforts to address leadership development needs. It discusses current thinking about leadership, reviews a current popular trend in professional development for librarians, and presents a case study of a new leadership institute offered by the Pacific Northwest Library Association (PNLA), a bi-national organization that serves a large region spread over the western United States and Canada. A summer of preliminary participant evaluation and survey data concludes the paper.
\end{abstract}

\section{Leadership in the library profession}

Concerns about library leadership today are as multi-faceted as they are widespread. We are worried that not enough people will enter the profession at a time when so many are retiring. We worry that those who have joined the profession recently, with their advanced technical knowledge and focus, are fundamentally different from traditional librarians. Those currently in the profession are experiencing stress from the work of navigating constant change. This makes our present work force feel over-loaded and not well equipped to lead libraries through the chaos of accelerating ethical, political, fiscal, and technical challenges facing them today. All of these factors enter into our discussions of succession planning, leadership, and the basic future of the profession.

Our concerns could fill pages. Fortunately, so could the solutions that are being explored all over the world. Library leadership development is a particularly hot topic in the United States and in Canada. The result is an ever growing set of options for developing those qualities that make one a leader in librarianship. This paper focuses on one region's efforts to address leadership development needs. It discusses current thinking about leadership, reviews a current trend in professional development for librarians, and presents a case study of a new leadership institute offered by the Pacific Northwest Library Association (PNLA), a binational organization that serves a large region spread over the western United States and Canada.

\section{Definitions of leadership}

Definitions of leadership are even more varied than our concerns about it. Donald E. Riggs counts "at least 100 definitions of leadership...includ[ing] leadership styles, functional leadership, situational leadership, bureaucratic leadership, charismatic leadership, servant leadership, follower leadership, group-centered leadership, and so on". Diversity of definition is further deepened when cultural differences are considered within and across countries. $^{2}$ 
This does not mean that some common trends in leadership development are not emerging in North American libraries. Generally, in the United States when we talk about 'leadership' in libraries today, we do not limit our discussion to those who fill the highest positions - directors, deans, department heads, or presidents of associations. Nor is leadership seen, as it traditionally has been, as an exclusive society at the top of the management hierarchy. Leadership is now more often looked upon in a democratic light, as a varied set of attitudes, qualities, skills, and tools that any committed person, in any library position, might develop and employ. Works such as Ira Chaleff's The Courageous Follower have helped to redefine and broaden the concept of leadership to embrace the possibility of leading from any position. $^{3}$

Likewise, 'leadership' and 'management' are generally no longer considered synonymous, although they are still likely to be confused. Warren Bennis's often quoted work On Becoming a Leader distinguishes between leaders and managers in a list that reads like the differences between the good guys and the bad guys in American westerns: a leader innovates, originates, develops, focuses on people, inspires trust, looks long range, watches the horizon, challenges, is her own person, and does the right thing. A manager pretty much does the opposite, according to Bennis. ${ }^{4}$

Bennis's point in drawing such a stark contrast is to underscore his basic premise "that leaders are people who are able to express themselves fully...[T]hey know who they are, what their strengths and weaknesses are, and how to fully deploy their strengths and compensate for their weaknesses. They also know what they want, why they want it, and how to communicate what they want to others, in order to gain their cooperation and support. Finally, they know how to achieve their goals.” Leaders tend toward action and innovation, propelled forward by the internal power of self-knowledge.

Read within a cultural context, it is easy to see why it is appealing to North American institutions to define leadership as highly individualized and democratic. In the current library environment of intense change, it makes sense that our definitions of leadership are colored by the need for decisive action and heroic accomplishment in the face of seeming chaos. This, in turn, influences the leadership development programs we create.

\section{Leadership institutes}

One of the primary ways library leadership development is being addressed today is through leadership institutes. These institutes are usually brief (3-5 days), intense learning experiences geared toward small groups of librarians or library workers (20-40 participants) in various career phases and positions. They usually involve some residency component, and also use facilitators or instructors, and mentors. Some include follow-up activities carried out over one or two years. Library leadership institutes are not unique to the United States Australia's Aurora Leadership Institute has been in place since 1995. Canada's Northern Exposure to Leadership began in 1994. The South Africa Library Leadership Project (SALLP) began in 2002 and involves some training in the US, as well as on-going group contact. $^{5}$ Additional non-institute leadership experiments taking place outside the US are also reported in the literature and include the Christchurch City Libraries (New Zealand) "coaching quads". 6

In the United States, leadership development initiatives in the form of intensive institutes have been offered at different levels and locations since the early 1990's. A growing number of state-level leadership institutes are being offered. Some of the most established include Ohio Library Leadership (since 1993), TALL (Texas Accelerated Library Leaders) Texans Leadership Development Institute (since 1994), the Maryland Library Leadership Institute (since 1998), the Nebraska Library Leadership Institute (since 2001), and the 
Wyoming Library Leadership Institute (since 2001). These local institutes vary in contact time and frequency and are targeted toward librarians within their state, often both degreed and non-degreed with varying levels of experience.

On the national level, several high-profile leadership institutes are offered. One of the first, the Library Leadership Institute at Snowbird (Utah) (since 1990, recently suspended indefinitely) is not geographically limited. It draws participants and mentors from around the country and frequently from other countries as well. Another nationally defined institute is the Association of College and Research Libraries (ACRL) / Harvard University Leadership Institute for Academic Librarians (since 1999), which is focused on higher-level administrators. These national institutes are usually very specific in their applicant requirements, which usually include a Masters in Library Science or some other American Library Association (ALA) accredited degree as well as other specific criteria such as number of years in the profession or management position.

In between these state and the national level institutes is an emerging category of regional library leadership institutes developed and supported by regional library associations for their member chapters. These regional institutes often serve a large geographic area and help to fill a leadership development need that individual state chapter associations would find expensive to fill on their own.

The annual Mountain Plains Library Association (MPLA) Leadership Institute serves the twelve MPLA member states of Arizona, Colorado, Kansas, Montana, Nebraska, Nevada, New Mexico, North Dakota, Oklahoma, South Dakota, Utah, and Wyoming. Participants are required to hold an MLS, have less than 10 years post-master's work in a library related job, work in the region, and belong to one of MPLA's affiliated state library associations.

The New England Library Association (NELA), covering a 6-state region including Connecticut, Maine, Massachusetts, New Hampshire, Rhode Island, and Vermont, has launched the biennial New England Library Leadership Symposium (NELLS). NELLS is focused on a broad spectrum of library personnel, including professionals, paraprofessionals, and volunteers (trustees or friends) who are in mid-career with at least 3-5 years experience in or with libraries, and who must belong to one of the six NELA state associations. The MLS is not required.

The newest regional library leadership institute to emerge is the Pacific Northwest Library Association's (PNLA) Leadership Institute, first delivered in fall 2004. Because of the unique bi-national nature of PNLA and its region, the recent development of its institute is of special interest to the global library community. What follows here is a case study of PNLA's first institute, including the planning, delivery, participant and mentor profiles, and initial participant response.

\section{One region's answer to leadership development needs}

One of the oldest regional library associations (1909), PNLA has a membership that today hovers around 350. It serves a large geographic area spread across the farthest northwestern reaches of North America including library association chapters in the US states of Alaska, Idaho, Montana, Oregon, and Washington, and the Canadian provinces of Alberta and British Columbia. Together, these entities cover a landmass of 1,684,795 square miles, adding up to a vast region characterized by relatively scattered population pockets, bisection by a national border, and wide economic variances.

PNLA's mission is to "provide opportunities in communication, education, and leadership that transcend political boundaries,....meet continuing education needs of the region [and] develop stronger library networks and networking...”? Gathering input from chapter associations and monitoring trends and events in the region are considered essential 
for fulfilling this mission. To facilitate this, a representative from each chapter state and province sits on PNLA's governing board.

PNLA's initial exploration of a regional leadership institute came as a direct result of input from its chapters. The idea came before the board in spring 2001 at the request of then president of the Oregon Library Association, Anne Van Sickle. Input gathered in 2002 from other member associations indicated that there was significant interest in PNLA taking the lead on developing such an institute at the regional level. In particular, chapter associations expressed concern over their individual abilities to deliver the kind of intensive professional development opportunity necessary to grow leaders who would become further involved in professional associations at the state, regional, and national levels, and who could step into management positions in libraries. The lack of local leadership development opportunities was keenly felt in a region that is predominantly rural and is challenged by great distances between cities. In addition few local MLS programs are available, and distance MLS programs are often prohibitively expensive in comparison with generally low wages for the non-degreed librarians who direct many rural libraries in the region and fill key positions in others. Funding for professional development across the region is decreasing as government funding for state and provincial libraries is cut. The budgets of chapter associations are often strained to fulfil increased membership needs in lean years.

As a result of this input, PNLA agreed to explore further the feasibility of a centrally administered leadership institute that would address the special needs of libraries in the region, capitalize on the strengths of a bi-national population, and, as a side benefit, heighten the profile of PNLA in the region.

\section{Planning the PNLA Leadership Institute}

In 2002 PNLA President Sandy Carlson (formerly of Kitsap Regional Library, Bremerton, Washington) formed a subcommittee composed of several state and provincial representatives on the PNLA board to identify options and sketch out a proposal. They turned for research assistance to several students at the University of Washington (Seattle) Information School who were asked to survey the characteristics of selected library leadership institutes currently being offered around the US and Canada. As well as identifying several possible models, budget options, and assorted best practices, their research identified consultants working in the area of leadership training who could potentially lead PNLA's institute. $^{8}$

In early summer 2003, a request for proposals (RFP) was sent out to several consultants. Of those returned, Schreiber Shannon Associates were chosen by the Board for the quality of their curriculum, their experience, and their success record, which includes the Australian Aurora Leadership Institute and the Leadership Institute at Snowbird. At least one member of the planning committee had attended an institute lead by them and highly recommended their work. We could see that these consultants would help PNLA deliver a leadership development experience that would go beyond basic skills into the realm of selfdiscovery and visioning.

A major concern, of course, was how the institute would be financed. PNLA's goal was to make participation as affordable as possible while still delivering a quality experience. To do this we followed a model that several other institutes have used: a combination of funds contributed by the lead institution (PNLA), seed money from stakeholders (PNLA's member associations), some corporate sponsorship, and registration fees. Fees for participants were set at $\$ 1,000$ each, payable in the currency of the participant's country, a concession that helped to make the institute equally affordable for both US and Canadian participants. 
Location was also a key consideration. Dumas Bay Centre, a retreat and community arts facility owned by the city of Federal Way, Washington, located just outside Seattle, was chosen for its relatively central location near a major airport (SeaTac), for its affordability, and privacy. PNLA has used this center for board meetings for several years and was well aware of its strengths and weaknesses. Timing was critical for the institute. Planners decided on October 24-29, 2004 because of fewer professional conflicts, and the availability of the facilitators and of Dumas Bay Centre. Choosing to deliver the Institute sooner rather than later required a leap of faith of the highest order. While some might have been more comfortable waiting until 2005, the majority of the board agreed that current momentum was strong and that everything would come together.

With key components of facilitators, budget, location, and dates in place, the planning committee and PNLA Board turned to address other critical matters such as potential mentor identification and selection, the application process, and participant selection criteria. In Fall 2003 Susannah Price (Boise Public Library, Boise, Idaho), a recent past PNLA President and Idaho Representative, took over as coordinator for the Leadership Institute when Carlson's commitments would not allow her to continue in that role. Under Price's leadership the Board developed a plan for mentor and participant selection, as well as an application package.

\section{Mentor selection}

Quality of mentors can determine the success or failure of a professional development activity so it was important to lure excellent mentors from around the region. Eight mentors would need to be recruited to provide sufficient one-on-one contact for the anticipated 36 participants who would be divided into 4 learning groups. Finding mentors who represented the various PNLA chapters was considered a priority so the planning committee came back to the board for nomination of appropriately experienced and committed librarians from around the region.

Although initial nomination was up to each representative, the board discussed all options before deciding whom to invite. Considerations included type of library, gender, and position or profile in the profession. Mentors were not required to be members of PNLA. It was decided that two potential mentors from each state and province would be approached to determine interest and availability. If open to serving as a mentor, their names would be placed into a pool. Once this pool was formed the Institute coordinator developed a draft list of mentors that would provide an optimal mix of location, library type, and gender. The board reviewed the list and gave approval to invite selected mentors. Mentors were assured that their room and board expenses would be covered and that some travel expenses would also be reimbursed.

Mentors were enthusiastic and the acceptance rate was high. Each of the seven chapters was initially represented in the pool and the current PNLA president rounded out the group to total the necessary eight. One mentor subsequently dropped out and no other from that chapter (Washington) could be located at the time so another chapter's alternate was invited instead. Our mentor selection process resulted in the following mix:

- $\quad$ gender: six women and two men,

- $\quad$ library type: 4 from public libraries, 2 academic, 1 school, and 1 corporate.

- $\quad$ nationality: 6 US and 2 Canadian

- $\quad$ leadership experience: an ALA past president, a PNLA president, 4 past presidents of state or provincial library associations, 3 department heads, and 4 library or branch directors.

- $\quad$ education: all mentors held an MLS degree (although this was not required) 
- $\quad$ leadership training: half had participated in some other leadership institute such as Snowbird or Northern Exposure.

\section{Selecting future leaders}

The PNLA board took determination of applicant criteria very seriously. Our research into other institutes revealed a broad range of possible selection criteria, including educational attainment and management experience, but input from PNLA's member associations signaled that similar criteria would not work for this region. It was decided instead to offer equal opportunity for degreed and non-degreed librarians with a wide range of library experience ( $5-15$ years).

This was a difficult decision to make. We knew that through openness we might risk diluting the experience or placing incompatible experience levels at the same table. Yet across the Pacific Northwest we were witnessing non-degreed librarians increasingly called upon to play leadership roles in their associations or institutions. It was also felt that in the midst of tremendous change in the library profession and in the North American west generally, it is not just new librarians who need to develop leadership abilities. Librarians might in their 5th or 10th or 15th year be called upon to fulfil hitherto unheard of roles or might discover new opportunities that required equally new leadership abilities.

Diversity was another issue. For a predominantly female profession working in a region that has pockets of ethnic and racial diversity but is primarily white, we knew that lack of diversity in participants might be a difficult hurdle to overcome. The diversity we chose to pursue for our first institute, then, was that of education, experience, and position. We felt that enabling a unique mixture that prioritized professional diversity would offer opportunities for interaction among groups who might rarely sit as equals at the same table, enabling high levels of discovery and self awareness irrespective of organizational hierarchies, levels, or lines - something that many libraries are trying to grapple with internally as they develop new ways of dealing with rapid change.

We also chose not to require nomination, keeping the application process very open. Instead, we asked applicants for a letter of support from an employer, library association, or school; two letters of recommendation; a one-page resume; and a one-page summary of achievements, career goals, and expectations of the institute. The board and planning committee also decided to prioritize their selection of applicants based on geographic location. Since most chapters of PNLA had contributed seed money to the institute, we felt it was important to select a base-line number from each chapter. We placed the optimal number of participants at 36, or 4 groups of 9 each. Thus, states or provinces whose applicant numbers totalled 4 or fewer were assured that all their applicants would have a space at the table. Of those with more applicants (Alaska, Oregon, Idaho, and Washington), other selection factors (quality of application, experience, and references) came into play. This ensured that each state or province in the PNLA region had at least one participant and could see some return on its investment.

\section{A snapshot of participants}

Out of 41 applications received, 36 participants were selected. Our commitment to representation from around the region meant that we had a group whose experience and education were mixed. Of the 36 who attended, 32 were female (89\%) and 4 male (11\%). The average library experience per attendee was 9.5 years (our requirements were no more than 15 years and no less than 5). Of the 36 attendees, 25 (69\%) already play a leadership role in a library, either within a titled management position or in an untitled position that requires leadership skills. 11 (31\%) were not in leadership roles. 
Application requirements for the Institute stated that no degree was necessary for participation. The result was a mix of education levels dominated by the MLS degree.

Figure 1 Education variance between participants

\begin{tabular}{|l|c|c|c|}
\hline \multicolumn{4}{|c|}{ Education level of participants } \\
\hline Degrees earned & Number holding & Total \% & Notes \\
\hline No higher ed degree & 3 & 8.3 & \\
\hline Undergrad degree & 8 & 22 & (includes 1 MLS in progress) \\
\hline MLS degree & 21 & 58.3 & \\
\hline $\begin{array}{c}\text { MLS plus other post } \\
\text { undergrad degree }\end{array}$ & 2 & 5.6 & \\
\hline $\begin{array}{c}\text { Non-MLS post } \\
\text { undergrad degree }\end{array}$ & 2 & 5.6 & (includes 1 MLS in progress) \\
\hline
\end{tabular}

The geographic spread of participants was a natural result of the make-up of PNLA and our selection priorities (Figure 2). Although urban or rural dwelling were not selection considerations, the general availability and cost of professional development opportunities for those residing in rural areas was a significant consideration for PNLA in the planning of the Institute. Low numbers of Canadian participants indicate PNLA's lower profile in Alberta and British Columbia, reflected in membership numbers as well.

Figure 2 Distinctions between urban and rural based on 2000 census data.

\begin{tabular}{|l|l|l|l|}
\hline \multicolumn{4}{|c|}{ Geographic Location Of Participants } \\
\hline State or Province & Total & Urban & Rural $^{*}$ \\
\hline Alaska & 7 & 2 & 5 \\
\hline Idaho & 4 & 3 & 1 \\
\hline Montana & 4 & 1 & 3 \\
\hline Oregon & 9 & 8 & 1 \\
\hline Washington & 10 & 10 & 0 \\
\hline Alberta & 1 & 1 & 0 \\
\hline British Columbia & 1 & 1 & 0 \\
\hline Total & 36 & 26 & 10 \\
\hline Percent Total & $100 \%$ & $72 \%$ & $28 \%$ \\
\hline
\end{tabular}

'Rural' is defined as places with populations of less than 90,000 and not bordering larger metropolitan areas.

Type of library, while not a selection criterion, emerged as an important factor in terms of discussion focus during the Institute and has implications for future networking options for both participants and mentors. Not surprisingly, 66\% of participants came from public libraries; however all library types were represented in the participant pool (Figure 3). 
Figure 3 Institute participants by type of library

\begin{tabular}{|l|c|l|}
\hline \multicolumn{2}{|l|}{ Institute Participants By Type Of Library } \\
\hline Library type & No. of participants & $\%$ of total \\
\hline Public & 24 & $66 \%$ \\
\hline Academic & 6 & $17 \%$ \\
\hline Special & 4 & $11 \%$ \\
\hline School & 2 & $6 \%$ \\
\hline
\end{tabular}

Another requirement of all applicants was that they belong either to their state or provincial library association or to PNLA. In addition to specifically indicating their membership(s) in either or both of these bodies on their applications, participants also submitted a brief professional resume. These two pieces of information reveal that the majority of our successful applicants belong to a state or provincial association. Fewer belonged either currently or previously to a regional level association. Still fewer were members of any national library or information association. Active involvement in any of these organizations was identified by an assortment of activities - committee work, presentations at conferences, or offices held. Because PNLA's chapters were specifically interested in leadership training that would help provide more manpower for their associations, it is instructive to see that prior to the institute many participants identified themselves as members of various professional associations, but relatively few were active (Figure 4).

Figure 4 Relationship with library associations

\begin{tabular}{|l|l|l|}
\hline \multicolumn{2}{|c|}{ Relationship With Library Associations } \\
\hline Type of Association & Hold Membership In & Are Actively Involved In \\
\hline $\begin{array}{l}\text { State or Provincial Library } \\
\text { Assoc }\end{array}$ & $33(92 \%$ of total) & $15(42 \%$ of total) \\
\hline Regional Library Assoc & $16(44 \%)$ & $4(11 \%)$ \\
\hline National Library Assoc & $13(36 \%)$ & $8(22 \%)$ \\
\hline
\end{tabular}

The 5-day institute schedule was very tightly structured. The entire group numbered 48 (36 participants, eight mentors, two facilitators/consultants, and one coordinator and her helper) and we had very little time alone. Days were spent working variously in 'learning groups' (tables of eight plus two mentors) and in whole group learning and discussion. The group essentially spent 12 hours a day together, primarily in a large common room divided into tables for group work. Each participant had his or her own sleeping room at Dumas Bay, took most meals there, and used the grounds for exercise, introspection and socializing.

The Schreiber Shannon curriculum does not focus on rudimentary managerial skills such as budgeting or supervision. Group work was centered on activities designed for intense learning in areas such as conflict management, self-awareness, relation to change, collaboration, visioning, self-empowerment, and risk taking. The goal was for participants to experience in a safe environment the stressors that leaders feel in the real world. Participants then learned from their own reactions and interactions. Moving out of one's 'comfort zone' was actively encouraged in order to gain greater self-awareness.

Mentors were also part of this learning. They played a key role in reflecting back to their groups and to individuals what patterns and problems they saw. Mentors were not 
allowed to lead their groups, only to challenge, counsel, provide clarification, and at times provide in-depth information about their own struggles and successes as leaders.

While the rhythm of each day's work was very intense, it often mirrored what many of us see in our day-to-day library work: collaboration in group meetings interspersed with listening and learning, punctuated by individual work, then returning again to the larger group. The difference at an institute like this lies in the reflection, feedback, and attention that participants receive - things rarely experienced in our daily work.

\section{Participant feedback and follow-up}

Did the PNLA Leadership Institute work? How will we be able to tell if it did? Those are the big questions for PNLA and its chapters. Leadership development is notoriously difficult to measure or track with any scientific certainty. Exit evaluations from participants and mentors indicate predominantly positive responses to the institute. High marks were given for meeting our objectives and for the work of the organizers, consultants and mentors. Many comments ratified the planners' intentions. For instance, when asked, "What was your most significant learning from the institute?” some very powerful statements were made:

- I discovered that I must move toward personal achievement and toward a positive focus.

- $\quad$ Helped me to look inward at issues I've wanted to address.

- $\quad$ Leadership is a personal journey.

- I need to change my life.

More difficult to measure are the longer-term outcomes and impacts on participants' professional lives. Since leadership development is not easily quantified or 'calendared', it will be imperative that the developers of future PNLA institutes find ways to track professional progress and solicit meaningful feedback on the impact of the experience over time.

Steps are already being taken to ensure that this is done. A Web survey conducted 6 weeks after the institute provides further insight on possible professional impact. Of 36 participants surveyed, 33 responded, for a strong return rate of $91.7 \%$.

Responses give some indication of self-perceived impact on participants’ professional lives, particularly in the leadership skill areas targeted by the curriculum (Figure 5). When asked to respond to the statement, "Since my return to work, I have used skills I learned at the Institute,” 18.2\% strongly agreed, 69.7\% agreed, 3\% were not sure, and 9.1\% disagreed.

Figure 5 Respondents reporting gains in leadership skills as a result of the institute

\begin{tabular}{|l|c|}
\hline Leadership Skills & Participants Reporting Gain \% \\
\hline Conflict Management & 79 \\
\hline Self Awareness & 97 \\
\hline Collaboration & 85 \\
\hline Visioning/Idea Generation & 84 \\
\hline Self Empowerment & 79 \\
\hline Risk Taking & 88 \\
\hline
\end{tabular}

The survey also provides some measure of the impact the institute may have on the future professional activities of the participants. When asked, "Because of this Institute, do you feel you will be more likely to pursue any of the following in the future," some heartening answers were given by the 31 participants who responded to this question (Figure 6). 
Figure 6 Interest in future professional activity as indicated by respondents

\begin{tabular}{|l|c|c|}
\hline Potential Activity & Response \% & $\begin{array}{c}\text { Response } \\
\text { Total }\end{array}$ \\
\hline Involvement in my state library association & 77.4 & 24 \\
\hline Involvement in PNLA & 51.6 & 16 \\
\hline Involvement in the American Library Assoc. (ALA) & 16.1 & 5 \\
\hline Management positions in libraries & 58.1 & 18 \\
\hline Further academic education & 35.5 & 11 \\
\hline
\end{tabular}

\section{Implications and plans for the future}

Further follow-up on the professional progress of this first cohort will need to be made in order to determine the long-term benefits of the PNLA Leadership Institute. Initial evaluation and survey input indicate that the institute was successful in the short term. Further tracking of participants' professional activities and attitudes will reveal more useful information.

If survey response is any indicator, this is a group that will make a difference to the state and provincial associations to which they belong. An electronic discussion list has been set up for the group and participants are already using it to plan reunions and presentations at the 2005 PNLA conference in Sitka, Alaska, and at the Oregon Library Association conference in Portland. State and provincial representatives on the PNLA board are following up by contacting participants to see how their professional reentry is going.

For the time being, based upon participant and mentor responses, the PNLA board has decided that it will repeat the institute again in Fall 2006 with some significant changes:

- $\quad$ a new coordinator has stepped up (Mary DeWalt, Ada Community Library, Boise, Idaho),

- $\quad$ location will be moved to a more group-work conducive setting,

- $\quad$ costs for participants will be lowered through increased corporate sponsorship and/or grant funding,

- $\quad$ the years of experience span may need to be narrowed,

- $\quad$ more Canadian participation will be solicited to further enrich the diversity of the institute,

- $\quad$ advertising and marketing will need to be increased.

PNLA's time and effort in delivering a leadership development option for the Pacific Northwest have born healthy fruit, it appears, and the association's commitment to serving the needs of the region in this area of professional concern will continue.

\section{References}

${ }^{1}$ Riggs, D. E. The crisis and opportunities in library leadership. Journal of Library Administration 2001, 32 (3/4), 5-17.

${ }^{2}$ Li, Haipeng. Le. Leadership: an international perspective. Journal of Library Administration 2001, 32 (3/4), 177-195.

${ }^{3}$ Chaleff, I. The Courageous Follower: Standing Up To and For Our Leaders. San Francisco: Berrett-Koehler Publishers, 1998.

${ }^{4}$ Bennis, W. On Becoming a Leader. Reading, Mass: Addison-Wesley Publishing, 1989.

${ }^{5}$ Thomas, G. Building bridges: LIASA and leadership development in South Africa. IFLA Journal 2002, 28 (5/6), 298-307.

${ }^{6}$ Dawson, D. Leadership development in libraries. Aplis 2002, 15 (4), 155-159. 
${ }^{7}$ Pacific Northwest Library Association. (2004) Mission and Goals. URL $<$ http://www.pnla.org >

${ }^{8}$ Fraser, L., Appel, E. \& Shaw, K. Summary of Findings on Leadership Institutes Prepared for the Pacific Northwest Library Association. [Unpublished]. February 2003. 